\title{
Urgences
}

\section{Tout vient du fait...}

\section{Vianney Gallant}

Numéro 15, octobre 1986

Épigraphiques

URI : https://id.erudit.org/iderudit/025326ar

DOI : https://doi.org/10.7202/025326ar

Aller au sommaire du numéro

Éditeur(s)

Urgences

ISSN

0226-9554 (imprimé)

1927-3924 (numérique)

Découvrir la revue

Citer ce document

Gallant, V. (1986). Tout vient du fait... Urgences, (15), 63-63.

https://doi.org/10.7202/025326ar

Ce document est protégé par la loi sur le droit d'auteur. L'utilisation des services d'Érudit (y compris la reproduction) est assujettie à sa politique d'utilisation que vous pouvez consulter en ligne.

https://apropos.erudit.org/fr/usagers/politique-dutilisation/
Cet article est diffusé et préservé par Érudit.

Érudit est un consortium interuniversitaire sans but lucratif composé de l’Université de Montréal, l'Université Laval et l'Université du Québec à Montréal. Il a pour mission la promotion et la valorisation de la recherche. https://www.erudit.org/fr/ 


\section{Vianney Gallant}

Le mensonge n'est que la forme bâtarde du songe.

Jean-Louis Major: Entre l'écriture et la parole

Tout vient du fait que le songe initial fut perçu dans un miroir, accouché comme un concept. Le géniteur a fait déborder la poudre du verre sanglant des croisades. Il a donné forme d'hydre à l'oiseau, à son foie, viscères de la banalité du regardant. Il s'est brisé sept fois l'échine du discours, n'a pas assumé l'origine du postulat, prenant son désir pour l'objet et le sujet comme outil sinon comme autel; depuis, on fait la roue.

Mais avant, bien avant, en se contemplant dans un lac acide l'ombre d'un cumulus radio-actif avait déjà troublé sa vision - il est tombé en miettes avant même que l'étain ne s'éparpille. Il en a poussé des milliards, des songes violés, postulés au nom du Vrai invérifiable, des lobbyings du désert sous les tentes, dans les grottes, les stalactites du pouvoir ont percé tous les hymens. De ces cavernes à nos lanternes, le faire-valoir de l'ombre trône, émergeant des statues.

Mais le songe naît toujours. On le quadrille, le castre de modernité. On ne peut tolérer l'odeur du marais primitif, de la glaise épouvantail de la pulsion; on le maquille, il prend le maquis. Reste ce qui manque. Reste la sonde du concept chargée de tous les crimes et de tous les postulats légitimatoires. Reste le geste informel de l'émotion pour l'erreur amoureuse d'une interprétation vierge au risque du poncif.

En privilégiant la forme dans chaque domaine, on construit sur pilotis pour éviter l'odeur de l'échange. L'aseptique prend couleur de bonne conscience. Il était une fois l'enfant trouvé dans la coquille de l'oeuvre. Le discours prostitué brandissait, analytique, les bannières de Jeanne d'Arc. L'enceinte copulait dans les globules du septième jour. Il était une fois le mensonge d'une situation sans initiale. Et c'est signé: l'homme! 